\title{
The Legislature and Anti-corruption Crusade under Nigeria's Fourth Republic, 1999-2013
}

\author{
Eme, Okechukwu .l.
}

Onyishi, Tony A Ph.D

\author{
Department of Public Administration \& Local Government Studies \\ University of Nigeria, Nsukka, Enugu State \\ Email: okechukwunncnt@yahoo.com,okechukwunncnt@gmail.com
}

\section{Doi:10.5901/mjss.2014.v5n15p28}

\section{Abstract}

An attempt by the Federal Government of Nigeria to remove subsidy on Premium Motor Spirit (PMS) popularly known as fuel opened a Pandora's Box which stories are still developing till today. On the insistence and prompting of Nigerians that corruption and fuel had been subsidized all along, the House of Representatives set up an Ad Hoc committee to look into alleged irregularities in the fuel subsidy regime. The committee after its investigation discovered that N1.4 trillion had been unlawfully paid out to the treasury looters. This particular fraud is said to be the most monumental in Nigeria and in Africa considering that it is close to half the annual budget of Nigeria and that of about seven West African countries put together. Few months after the submission of the report of the Panel which included recommendations for appropriate sanctions to culprits, Nigerians were yet treated to another drama when Mr. Femi Otedola whose company Zenon Oil had been fingered as one of the beneficiaries of the loot, came out to say that the chairman of the Ad Hoc Committee Hon. Farouk Lawan had solicited for $\$ 3 m$ out of which $\$ 620,000$ had been paid out to enable Hon Farouk Lawan remove Zenon Oil from any complicity in the scam. To say that corruption, like cankerworm, has totally devoured the very fabric of the Nigerian polity is merely stating the obvious. That the cost of public and private sector corruption to the nation, over the years, is unquantifiable is rather stale news. Likewise the fact that the agencies saddled with the responsibilities of checkmating corruption and prosecuting corrupt individuals has not done enough. Even the judiciary has not helped matters. And the question remains: Is there a way out of the woods? This is where the role of the legislature in the anti-corruption initiative is critical given the centrality of the role of the legislature in the political process of a polity. This paper examines how the legislature has faired in performing its constitutional and oversight duties in this regard. It finds a wide gulf of difference between constitutional prescriptions and political realities in a country where the legislature itself is confronted by daunting corruption challenges.

Keywords: Corruption and Anti-corruption Crusade, Constitution and Oversight Functions, Legislature, Subsidy Scam and Investigative Panel.

\section{Introduction}

There are many unresolved problems in Nigeria, but the issue of the upsurge of corruption is troubling. And the damages it has done to the polity are astronomical. The menace of corruption leads to slow movement of files in offices, police extortion tollgates and slow traffics on the highways, port congestion, queues at passport offices and gas stations, ghost workers syndrome, election irregularities, among others. Even the mad people on the street recognize the havoc caused by corruption - the funds allocated for their welfare disappear into the thin air. Thus, it is believed by many in the society that corruption is the bane of Nigeria. Consequently, the issue keeps reoccurring in every academic and informal discussion in Nigeria. And the issue will hardly go away.

It is a shame that the fight against corruption in Nigeria has not only stalled, so much talk about it does not seem to move to action, those who should be prosecuting the war.

Corruption, identified as the bane of Nigeria's development, must however, be fought to its end and talks about it can never be enough. Mercifully, three major events have recently, kept the issue on the front burner of national discourse. First, the Transparency International 2013 Report which ranked Nigeria 144th most corrupt country among 177 countries. Secondly, the African Development Bank (AfDB) recently revealed that $\$ 2.6$ trillion is stolen annually through high-level corrupt practices on the continent. While the ripples of these revelations were still being felt, a third occasion to discuss corruption came via the 2013 International Anti-Corruption Day marked by the Nigerian Bar Association (NBA). There, those in power too had a chance to bare their minds on the problem of corruption bedeviling the country. Speaker of the House of Representatives, Aminu Waziri Tambuwal, of course, joined the fray, and underlined the deepening 
impunity in government circles.

In particular, the poor performance of the anti-graft agency, Economic and Financial Crimes Commission (EFCC) came under the critical lens of the Speaker. The influx of funds from grant-making bodies which has not been accounted for was specifically mentioned. The Speaker also questioned the pension fund scam, the misapplication of funds in the Security and Exchange Commission (SEC), the continuing illegality of the Federal Executive Council acting as a contract clearing house despite the constitutional remit of the Bureau of Public Procurement to that effect and bureaucratic double standard over which the relevant organisations have refused to act. Mr. Tambuwal(2013:5) said:

In some cases, you have the government setting up new committees to duplicate the job already done by the parliament. Take the bullet proof cars case, the NSA, with all the security challenges confronting the country, should not be burdened with a job that can best be handled by the anti-corruption agencies. He also said the government has no business setting up any administrative committee in a corruption case that is clear to all Nigerians, in apparent reference to the committee set up by Mr. Jonathan to probe the N255 million car scandal involving the Minister of Aviation, Stella Oduah. The three-man presidential committee had since submitted its report to Mr. Jonathan, with the president taking no action. What the President should have done was to explicitly direct the EFCC to probe the matter. With such directives coming from the President, I am sure we still have good people in EFCC who can do a good job. By the action of setting up different committees for straightforward cases, the president's body language doesn't tend to support the fight against corruption.

However, the Speaker seemed to have patted the back of the National Assembly which he claimed had done its oversight function provided for in the constitution. He claimed that the legislature had carried out probes and whose reports the relevant organisations had refused to pursue to logical conclusion. In the exercise of their disciplinary measures, according to him, the legislature had not spared any of its erring members such as Farouk Lawan who was suspended from house committees following his indictment. Besides, the House had passed into law the Freedom of Information Act (FOIA) to aid citizens' action in curbing corruption in the country. This is impressive talk.

There is no doubt that the body language of the Presidency, as Tambuwal posited, not only seems to encourage corruption, it actually embraces it. And this is a tragedy for Nigeria. But is it possible to exonerate the National Assembly from charges of corruption? The Speaker also decried Jonathan's penchant for setting up committees to probe corruption allegations and what he termed "the culture of undue secrecy surrounding the operation of government."

Reacting to this statement, Comrade Debo Adeniran censured Tambuwal over his comment that Jonathan has been encouraging corruption in the country and attributed the alarming rate of corruption proliferation in the country to, not only the executive, but also the legislative arm of the government. He said,

This is a shameless statement from an inactive control system. Mr. Speaker should realise that the National Assembly is a part of the whole. It is fair to remind Tambuwal that his allegation has left no arm of the present government vindicated of corrupt practices. Had it been the House of representative had played its oversight functions - as stipulated by constitution - it would not have been that easy for corruption to fester in the country. By law, the House of Assembly can influence the decision of the executive to a large extent. But the question is, to what extent has the entire federal Assembly used this constitutional privilege? What is the principle of separation of powers for, is it not for checks and balances? Speaker Tambuwal lacks the moral ground to either accuse Jonathan of corruption or shift the blame on any other persons, because he is also guilty as he had alleged (Muktar and Muktar, 2013:7).

He added:

This is a Speaker of the House of Representatives which has been busy enacting laws to protect the interest of the corrupt public officers. What is the motivation behind the bill meant to legalize foreign account for public office holder? What benefit will that be to the masses of this country? Criticising the Executive Arm on the pages of newspaper is not a way to perform oversight functions. As a matter of fact, it makes a mess of whatever effort the lower house may have put in place to stem the tide of corruption(Muktar and Muktar, 2013:7).

There are many clauses in the 1999 Constitution that empower the National Assembly to monitor the country's resources. For example, sections 59 and 80-89 give full powers to the National Assembly to appropriate funds for the running of the affairs of the country and also to act as watchdog over the use of the resources by ways of horizontal accountability and by means of its powers over the Auditor-General of the Federation. Sections 80(3) states that 'no money shall be withdrawn from any public fund of the Federation, other than the Consolidated Revenue Fund of the Federation, unless the issue of those moneys has been authorized by an Act of the National Assembly.' And of course, it must be done in the manner laid down by the National Assembly as stated in Section 80 (4) of the constitution. Also, Section 85 (4) specifically states that 'the Auditor-General shall have power to conduct periodic checks of all government 
statutory corporations, commissions, authorities, agencies, including all persons and bodies established by an Act of the National Assembly'.

Above all, the power of impeachment engrossed in Section 143 gives the Assembly the teeth to bite the executive. The National Assembly has yet to exploit this for effect.

The charges of corruption are grave and daily, the impression is given as though the executive has all the power in the world to make and unmake despite constitutional provisions to the contrary. It is in this context that the submissions of the Speaker, good as they sound, would amount to grandstanding intended for an audience already overwhelmed by maladministration of government. It should be emphasized that there is danger in riding roughshod over the people. For sure, the large-scale corruption pervading the country amounts to impunity.

\section{Contextualizing Corruption}

It is axiomatic to posit that there is no single, comprehensive and universally accepted definition of corruption. It would be a long and cumbersome process to come up with a universally shared definition. To come up with such a definition one would in any event require a functional democracy that involves consultation and consensus by relevant stakeholders. The United Nations Office on Drugs and Crime in the Global programme against corruption - UN Anti-Corruption. Tool kit (2007) succinctly posits that the difficulties encountered in formulating a common definition are due to legal, criminological and political problems (UN Anti-corruption Tool kit, 2007).

Senior (2006:24) adds that the problems of coming with a convincing definition to the shades of corruption founds in Heindenhimer (1989) and Heindenhimer et al, (1993).

In view of the above difficulties associated with definition, it is often even more difficult to agree on the necessary punishment of the act itself. Though there are technical hitches in agreeing on a common universal definition, it is extremely significant to define corruption so that the actions of individuals and institutions can be judged as corrupt or uncorrupt.

In the definition shared by most political scientists, political corruption is any transaction between private and public sector actors through which collective goods are illegitimately converted into private-regarding pay offs (Heidenheimer, et; al, 1996:6).

It is a behaviour that abuse societal legal or social standards as well as public role or resources for private benefit (Johnston, 1991). Klitgaard's (1991) explanation of the concept followed similar pattern. According to him, corruption is the misuse of office for private ends. These definitions, however, narrow corruption to the public sphere because they are concerned with political corruption as against corruption in the private sphere. Attempt to broaden the definitional scope of corruption prompted Kobonbaey (2004) to define it as the abuse of formal rules of the game by actors for their private gains. Although Kobonbaey notes that this definition is in-exhaustive, it nevertheless captured all types of actions and organizations (public, private and non-governmental).

By this, any individual, either a public officer or private operator who deliberately refuses to follow due process in the course of carrying out his or her assigned responsibility for the purpose of personal gain is engaging in corrupt practices. At the center of corrupt behaviour, therefore, is the motive for private gain, either as private citizen or public officer.

This definition does not, however, distinguish clearly between political and bureaucratic corruption. It establishes the necessary involvement of the state and state agents in corruption, without any notion as to the level of authority where corruption takes place (Amundsen, 1999:3).

Amundsen (1999) goes on to posit that in a more strict definition, political corruption involves political decisionmakers. Political or grand corruption takes place at the high levels of its political system. It is when the politicians and state agents, who are entitled to make and enforce the law in the name of the people, are themselves corrupt. Political corruption is when political decision-makers use the political power they are armed with, to sustain their power, status and wealth. Thus, political corruption can be distinguished from bureaucratic or petty corruption, which is corruption in the public administration, at the implementation end of politics.

In a broad term, political corruption is the misuse of government officials of their governmental powers for illegitimate private gain. Misuse of government power for other purposes, like repression of political opponents and general police brutality, is not considered political corruption. Illegal acts by private persons or corporations not directly involved with government are not considered as political corruption either (Babylon's free Dictionary, 2008).

The International Monetary Fund Manual on Fiscal Transparency (2007) defines political corruption as the misuse by government or political officials of their governmental powers and resources for illegitimate, usually secret, private gain. 
Chinhamo and Shumba (2007) on the other hand define the term as the abuse of public power; or resources by government officials or employees for personnel gain. For example, extortion, soliciting or offering bribes.

As indicated earlier, even when the distinction between political or bureaucratic corruption is rather ambiguous as it depends on the separation of politics from administration (which is unclear in most political systems), the distinction is vital in analytical and in practical terms. Political corruption occurs at the top level of the state, and it has political repercussions.

The Southern African Development Community in the protocol against corruption defines corruption as "any act referred to in Article 3 and includes bribery, or any other behaviour in relation to persons entrusted with responsibilities in the pubic and private sectors which violates their duties as public officials, private employees, independent agents or other relationships of that kind and aimed at obtaining undue advantage of any kind for themselves or others" (SADC, 2007:1).

Chinhamo and Shumba (2007) posits that the above definition is more detailed as compared to Johnston (1996) Nye (1967); Friedrich, 1966, Van Klaveren, 1989, Heindenheimer, 1989 since it recognizes that corruption also takes place in the private sector and other settings.

What is also important about the SADC definition is that it gives the leeway to include acts of corruption that are hidden in the contemporary democratic processes. For instance, cases of rigging elections, putting in place biased electoral institutions and processes, abusing national resources for political gains, hijacking of law enforcement agents, and vote buying. There is however, need for such acts to be clearly spelt out in the list of acts of corruption, which the SADC did not do (Chinhamo and Shumba, 2007:3).

The above notwithstanding, it is significant to state that there are some forms of corruption that do not necessarily cause damage or loss. In this regard, there are some laws and legislations that have been made and amended to give an advantage to some politicians so that they can retain power. In Nigeria, the constitution and laws such as the public order act and some sections of the amended constitutions have been crafted in such a way that it will be difficult for the opposition political parties to effectively participate in politics and meet there constituencies. This has helped to keep the PDP in power since 1999. It is not clear whether the damage and loss referred to include such cases.

It is significant to make some observations on the many definitions given above:

1. Defining corruption as the abuse of public office for private gain is too narrow because there are many more phenomena that deserve the label "corruption" than those involve the abuse of public office for private gain. For instance, corruption scandals in Germany, France, and the United State that involved the illicit party funding than individual gain, there are also other elections in Africa (Zimbabwe and Nigeria) whose results were allegedly subverted. This idea is supported by Warren (2004) cited in Chinham and Shumba (2007:5) who pointed out that the definition does not fit well in corruption of the democratic processes.

2. Some of the definitions are too broad and are subject to misinterpretation.

3. Most definitions given above take for granted that corruption takes place in the public sector yet it is also rampant in the private sector. This applies to all individuals who define corruption as the abuse, use or misuse of entrusted public power, office, and authority for private benefit (Senior, 2006).

4. The definitions do not hold responsible all those who fail or neglect to take measures or fail or neglect to exercise sufficient oversight in as far forces preventing and combating corruption is concerned.

5. It is also important to take that not all power, office, and authority is entrusted and

6. Not all acts of corruption result in damage or loss (Chinhamo and Shumba, 2007:5-6).

After putting into consideration all of the above issues, the paper will adopt (SADC 2007) definition as its working definition. According to SADC (2007:8), corruption is the abuse or complicity in the abuse of private or public power, office or resources for personal gain.

The definition has the following features:-

a. It recognizes that corruption takes place in the both private and public sectors.

b. It holds individuals and institutions that are involved in the abuse of power, office and authority vicariously responsible for corruption (Chinhambo and Shumba, 2007: 6).

Public officials are therefore, responsible for the abuse of power, office and authority if they neglect preventing and combating corruption when they are in position to do so. Executive agencies that employ a passive system of risk detection waiting for complaints to be made about corruption are also held responsible. Complicity in corruption should be extended to the three tiers of government; political parties, the law enforcement agencies and agents, the private sector businesses and the general populace. Impunity should also be seen as complicity in corruption. 


\section{The Legislature and Anti-corruption Crusade in Nigeria}

The major fight against corruption is carried out through the process of lawmaking. Section 4 of the 1999 Constitution of the Federal Republic of Nigeria (as Amended) provides that the Legislature is empowered to make laws for the good governance of the nation, which include enacting anti-corruption legislation that criminalizes corruption and provides for appropriate punishment for offenders.

Under the legislative function, Section 4 of the Constitution of the Federal Republic of Nigeria 1999 provides to the effect that the National Assembly shall have the power to make laws for peace, order and good government of the country. More specifically, under Section 15 (5) of the Fundamental Objectives and Directive Principles of State Policy, it provides, "The state shall abolish all corrupt practices and abuse of office". Again in Section 2 (2) (b) and (c)' government is enjoined to harness the resources of the nation for the common good and to prevent the concentration of wealth or the means of production and exchange in the hands of few individuals or of a group.

The responsibility of fashioning the legal framework for the fight against corruption and corrupt practices is thereby vested in the legislature. In the exercise of this mandate, the National Assembly has enacted the Code of Conduct Bureau and Code of Conduct Tribunal, The Economic and Financial Crimes Commission (Establishment) Act 2002 and The Independent Corrupt Practices and Other Related Offenses Commission Act 2000' for the purpose of investigating and prosecuting Public Officers and other persons suspected of involvement in corrupt practices. In both legislations, the Commissions are given extensive powers of investigation and prosecution to deal with all cases of corrupt practices and abuse of office that may arise. With respect to the specific objective of injecting transparency and accountability in the management of the resources of the nation, the National Assembly enacted the Fiscal Responsibility Act 2007 and the Public Procurement Act 2007. Both legislations make copious provisions aimed at engendering transparency and accountability in the public space. According to Tambuwal (2013), the provisions of these legislations and indeed others were diligently enforced significant milestones would have been accomplished in the fight against corruption and corrupt practices in Nigeria. Sadly however these Legislations are observed more in the breach by the majority including government and government agencies.

He adds that he is pleased to report that the House of Representatives is currently working on some proposals for the reform of these laws with a view to reinforcing the independence of the agencies administering these laws including their mode of constitution and disbandment. He therefore called on members of the Nigeria Bar Association and indeed all Nigerians to prepare to buy into these reforms by making their inputs now or when the time comes for Public Hearings. He equally commented that the other area which has been of great concern to the Legislature is the culture of undue secrecy that surrounded the operation of government. Whereas the 1999 Constitution enjoins in its Section 14 (2) (c) that "the participation of the people in their government shall be ensured in accordance with the provisions of this Constitution" government business tended to be run like secret societies to the exclusion of the citizenry. It was clear that this tended and was indeed intended to aid the concealment of corruption such that even in times of suspicion, members of the public including gentlemen of the fourth realm could not access public information.

The other function of the legislature is oversight of the other arms of government.

Legislative oversight refers to the power to review, monitor and supervise agencies, programmes, activities and policy implementation of the executive arm of government by the legislature. Section 4(2) of the constitution of the Federal Republic of Nigeria 1999 (as amended) vests the legislative powers of the Federal Republic of Nigeria in the National Assembly consisting of the Senate and the House of Representatives and the power extends to making laws for the peace, order and good government of the federation or any part thereof with respect to any matter included in the exclusive legislative list set out in Part 1 of the second schedule to the constitution. (See S.4(2) of the Constitution (as amended).

Section 88 mandates the National Assembly to investigate the conduct of affairs of any person, authority, ministry or government department charged or intended to be charged with the duty of or responsibility for

i. Executing or administering laws enacted by the National Assembly or

ii. Disbursing or administering moneys appropriated or to be appropriated by the National Assembly

The main object of investigation according to sub section 2 (a) and (b) of Section 88 is for law reform and to expose corruption, inefficiency or waste in the execution or administration of laws or administration or disbursement of public funds. Similar provision is made in Section 128 of the constitution for legislatures at the sub-national levels. Another critical role of the Legislature is the provision of adequate funding for Anti Corruption Agencies through appropriation. Unfortunately efforts to exercise this function by the legislature are often misconstrued by the executive arm and even some members of the public. Yet without adequate funding the anti corruption agencies cannot execute their functions satisfactorily. 
It is in exercise of this mandate that the House of Representatives and indeed the National Assembly has been carrying out oversight of government agencies and series of investigations or probes over allegations of corruption and corrupt practices. According to Tambuwal(2013:8):

As you are all aware, the legislature has over the years exposed several cases of corruption. It is important for me to stress once again at this stage that the mandate of the legislature is to expose corruption. It does not have further mandate to prosecute. That mandate of prosecution lies with the Executive and Judiciary. I have heard public comments to the effect that the public is tired of investigation by the legislature since the people indicted in their findings are never prosecuted and sanctioned. Let me reiterate that the Legislature will not abdicate its responsibilities on the account of inaction or negligence of another arm of government. If nothing else we will at least continue to name and shame. As noted earlier, the war against corruption is the responsibility of all and I call on the citizens of this great nation to rise in the exercise of their constitutional power to insist on the prosecution and sanctioning of persons indicted by the Legislature or by any agency whether public or private concerned in the fight against corruption.

According to Ndoma-Egba (2013) oversight responsibilities are carried out in two broad ways: "the police patrol" method and the "fire alarm" method. The "police patrol" method implies a continuous watchfulness or constant supervision of the Ministries, Departments, and Agencies of Government and bureaucracy; the same way that the police constantly patrols the streets to provide security. This type of oversight is usually costly in terms of funds and capacity. The "fire alarm" method on the other hand is conducted as a result of concerns by constituents; the public, or the media. It can also happen through whistle blowing. Unlike the police patrol method which is preventive and designed to pre-empt or prevent issues the "fire alarm" method is ex-post facto oversight as it deals with issues after they have caused a fire. It is usually cheaper in terms of funds and maybe costlier in terms of the damage that may have already occurred.

This section also vests all implied and interest powers of law making, including power of oversight in the National Assembly. If however there were any doubt regarding this, the doubt is vitiated by section 88 of the constitution which provides;

i. subject to the provisions of this constitution, each House of the National Assembly shall have power by resolution published in its journal or in the official Gazette of the Government of the Federation or direct or cause to be directed investigation into;

(a) Any matter or thing with respect to which it has powers to make law; and

(b) The conduct of the affairs of any person, authority, ministry or government department charged, or intended to be charged, with the duty or responsibility for;

i. Executing or administering the laws enacted by the National Assembly; and;

ii. Disbursing or administering moneys appropriated by the National Assembly.

Therefore, the National Assembly is vested with oversight powers including the powers to investigate any matter or thing within its legislative competence and the conduct of affairs of any person, authority, ministry or government department charged with the duty or responsibility for administering or executing the laws passed by the National Assembly, and any person, authority, ministry or government department with any responsibility howsoever of moneys appropriated by the National Assembly.

Section 88(2) of the 1999 Constitution provides that the powers conferred on the National Assembly under section 88 are exercisable only for the purpose of enabling it to;

(a) Make laws with respect to any matter within its legislative competence and correct any defects in existing law; and

(b) Expose corruption, inefficiency or waste in the execution or administration of laws within its legislative competence and in the disbursement or administration of funds appropriated by it (Ndoma-Egba, 2013).

Though the Constitution sought to circumscribe or limit the powers to subsections (2)(a) and (b) the powers conferred by those subsections (2) (a) and (b) remain very wide and extensive. These powers are further re-enforced by the powers conferred on each of the Houses (Senate or House of Representatives) or any of its Committees established under section 62 of the Constitution exercising its powers of investigation pursuant to section 88 to procure evidence, written or oral, direct or circumstantial as it may think necessary or desirable, and examine all persons as witnesses whose evidence may be material or relevant to the subject matter; require such evidence to be on oath; summon any person in Nigeria to give evidence at any place or produce any document or thing in his possession or under his control; issue a warrant to compel attendance; order payment of costs occasioned by his failure, refusal or neglect to obey the summons and impose times for such failure, refusal or neglect. Any fine so imposed is recoverable in the same manner as a fine imposed by court of law. These are quasi-judicial powers and have inevitably been the source of constant irritation to the executive arm of government. Unfortunately it is irritation that must be borne with fortitude and equanimity because it is the power that guarantees the growth of public institutions and facilitates public accountability. 
In the exercise of the mandate of oversight the legislature is able to audit both pre and post expenditure of agencies of government and to give appropriate direction on the administration and disbursement of funds and execution of programs and projects under the Appropriation Act. Indeed the Public Accounts Committee of both the House and Senate has the specific mandate to review the disbursement and administration of public funds by ministries, Departments and Agencies.

In the current dispensation, the National Assembly has conducted several investigative hearings by inviting government agencies like the Bureau of Public Employment, Ministry of Aviation, NNPC, among others, to ascertain or probe their activities within a given period in order to expose corruption, inefficiency or waste in the execution of their powers, or funds appropriated to these agencies. Regrettably, not much has come out of these; rather we have had scandals and all sorts of stories, fuel subsidy probe, power probe, among others.

The House of Representatives has said that over N4 trillion was spent from the service-wide vote without the approval of the National Assembly between 2004 and last year. The House Committee On Public Accounts said such huge expenditures breached section 80 of the 1999 Constitution.

Besides, the committee alleged that between 2005 and 2006, the Obasanjo administration spent N250 million to feed former President of Liberia, Charles Taylor and his family, who were on an asylum in the country. The World Court in The Hague jailed Taylor this year for crimes against humanity.

The Chairman of the Committee, Adeola Solomon Olamilekan (APC-Lagos) disclosed this recently while briefing newsmen at the National Assembly.

He stressed the expenditures made without parliamentary approval started from the government of President Obasanjo to Jonathan's.

Hon. Olamilekan said:

\begin{abstract}
Most of the expenditures to which the service-wide vote releases were deployed are routine in nature and did not qualify for emergency funding. For instance, between 2004 and 2012, N1, 284, 853, 731.20 was spent on publicity and publication of various government programmes; between 2004 and 2005 N250 million was spent on the upkeep of the former Liberian President, Charles Taylor, another sum of N1400,494.84.57 was also released from the service wide vote for the payment of judgment debts against the Federal Government(Nnochiri,2013:12).
\end{abstract}

According to him,

the Office of the Accountant-General of the Federation, Budget Office and the Ministry of Finance released to their various offices a total sum of N2,267,002,101 to a few auditors as audit fees and in 2011 alone, the Office of the Accountant-General of the Federation paid out the sum of N809,358,504 as audit fees to some external auditors carrying out audit of the Federal Government's financial activities instead of the Office of the Auditor-General for the Federation(Nnochiri,2013:12).

Hon. Olamilikan, in his committee's report, also alleged that over N160 million was released for the Budget and Accountant-General's offices. According to the report:

The expenditure of N162 million from the 2011 service-wide votes releases tagged; "Closing Accounts", incurred jointly by the Office of the Accountant-General and the Budget Office of the Federation. An expenditure of N1,059,177,589,31(\$6, $619,859.93$ at the rate of $\$ 1=\mathrm{N} 160$ ) in 2010 and 2011 was said to be payment of outstanding tax on Nigeria Housing in New York. Successive governments have from 2004 to 2012, spent a whopping and mind-boggling sum of N4.17 trillion as against N1.8 trillion approved by the National Assembly as service wide votes component of the budgets of those years, translating to N2.27 trillion extra-budgetary spending or 220\% above the service wide votes as approved in the budget for the period (Mutar and Mutar,2013:7).

He stated that: such extra-budgetary expenditures constitute a breach of Section 81 of the Constitution of the Federal Republic of Nigeria, 1999 (as amended) and an illegality. He said his committee discovered in the course of its oversight that the service-wide vote was converted to a recurrent fund by the government, instead of an infrastructure vote. Such releases were mainly used to finance recurrent expenses not targeted at critical and strategic sectors of the economy and the releases were random and did not follow any clear pattern. The service wide votes had become an alternative budget which government prefers to patronize than the annual budget, leading to poor implementation of the annual budget as approved by the National Assembly.

The Legislature in Nigeria has been interfacing with Civil Society Organisations in the fight against corruption and collaborating with them in the area of Legislative advocacy down to their constituencies. The $7^{\text {th }}$ National Assembly has committee on Anti-Corruption, National Ethics and Values, in the House of Representatives, they have Public Accounts Committee of both Houses, through which it carries out this struggle to tackle corruption in Nigeria. 
From the foregoing, the Legislature has enough constitutionally endowed powers to fight the scourge of endemic corruption in Nigeria and can make all the difference. But for the Legislature to effectively play a positive and resultoriented role in the fight against corruption, it is important that it is independent. Legislative independence is key to a result-oriented Legislature process in a democracy.

\section{Recommendations}

First, the current administration has a need to realize that heavens will not fall if corrupt past and present leaders are prosecuted and given significant jail terms. The National Assembly could perhaps begin the remediation process by a certain self-purge and penitence in terms of reviewing its outlandish packages which rank it among the highest paid in the world. It would be edifying for the Nigerian National Assembly to also learn from the resentment to even the tokenist salary increase proposed by the Independent Parliamentary Standards Authority (IPSA) for the British lawmakers over their insensitivity to the ongoing economic recession in that country, despite several years of salary freeze. It is only by such self-purge and the power of personal examples that the legislature can regain the moral high ground and be alive to its responsibility.

Secondly, the most important ingredient in the corruption fight is the political will from the topmost leader whom associates and friends would fall back on for intervention when the law enforcement officers begin to do their jobs. A state called Bihar in India fought theirs by sponsoring a legislation that created fast-track courts dedicated to corruption cases. That way, such cases were heard and concluded speedily, and over 66,000 people were jailed for acts that bordered on corruption. Nigeria can commence that immediately. We can create special-purpose courts that can give corruption quick attention. And as we do that, the judges must first be examined and if found guilty of corruption, prosecuted for a crime against the state.

With a clean judiciary comes the confidence in the state to be able to uphold justice and rule of law, two ingredients whose presence sends perpetually on exile sleaze and impunity. That as a matter of seriousness urgently ensuring the effective prosecution of those suspected of massive corruption in the fuel subsidy reports. That all outstanding corruption reports, including the House Committee report on the subsidy racket must be fully implemented and perpetrators effectively punished.

The National Assembly should conduct an independent investigation into the numerous cases and corruption charges lying pending against public office holders. Notable in case are the ones involving the Internal Affairs, the most recent case of SURE-P which warranted the resignation of the Chairman.

The President Goodluck Jonathan should not only take note, but also take a stand and live by example on the fight against corruption in the country. We are calling on Mr. President to stop romancing corruption which is the bane of our development or else Nigerians will hold him as the first enemy of the Nigerian Project. That government must take strong measures to prevent political corruption in our country by cutting down waste and duplication of resources as contained in our budgets as a measure of detecting corruption risks in governance.

\section{Conclusion}

The National Assembly has passed the Freedom of Information Act 2011 to enhance the right of access to public records and information about public institutions. There is a legislation that attracted massive public interest and it is our expectation that Nigerians will make maximum use of Freedom of Information Act so that the right created under this legislation in order to defeat the culture of undue secrecy in the running of government business.

While the constitution of the Federal Republic of Nigeria has given the responsibility of oversight on the executive to the legislature the same constitution has placed the responsibility of ensuring public accountability on every Nigerian. Chapter two of the constitution sets out the fundamental objectives and directive, Principles of State Policy; the objectives and ideals of government. We should demand no less than these objectives of government and this we must do by insisting of public accountability.

For the Legislature to retain and maintain the public trust in its constitutional responsibilities and oversight functions, it must operate above board. It must, as an institution, and its membership stand up to the harshest public scrutiny. 


\section{References}

Amundsen, I., (2000), Corruption Definitions and Concepts, Oslo: the Norwegian Agency for Development Cooperation (NORAD).

Diamond, L. (2004). "Building a System of Comprehensive Accountability to Control Corruption". In Adigun Agbaje, Larry Diamond, Ebere Onwudiwe (eds.), Nigeria's Struggle for Democracy and Good Governance: a Festschrift for Oyeleye Oyediran. Ibadan: University Press.

Eme, (2010). "Corruption in Nigerian Government Institutions: A Case of Police Equipment Fund. Journal of Liberal Studies, University of Nigeria, Nsukka, pp. 440-458.

Global Programme against Corruption (2001). Empowering the Victims of Corruption through Social Control Mechanisms. Washington D.C.: World Bank.

Greenberg, T.S., Gray, L., Schantz, D., Latham, M. and Gardner, C. (2009), "Stolen Asset

Recovery: Politically Exposed Persons - A Policy Paper on Strengthening Preventive Measures. Washington DC: World Bank.

Klitgaard, R. (1988), Controlling Corruption, Berkeley: University of California Press.

Langseth, P. (2001a). Helping Member States Build Integrity to Fight Corruption. Vienna: European Central Bank.

Langseth, P. (2001b). Value Added of Partnership in the Fight against Corruption. Paper Presented at the OECD Third Annual Meeting of the Anti-Corruption Network ofTransition Economies in Europe, held in Istanbul, Turkey from 20 to 22 March 2001. (Available on-line at http://www.odccp.org/adhoc/crime/ gpacpublications/cicp11.pdf

Mojeed O. Alabi, A. and Fashagba, J.Y. (2010), "The Legislature and Anti-corruption Crusade under the Fourth Republic of Nigeria: Constitutional Imperatives and Practical Realities," International Journal of Politics and Good Governance, Volume 1, No. 1.2 Quarter II $1189-1195$

Muktar, H. \& Muktar, F. (2013), "Legislature, not just Executive to Blame for Corruption - CACOL", Daily Independent, December, P. 7.

Ndoma-Egba, V. (2013), Legislative Oversight and Public Accountability, being text of the Speech at the 2013 Faculty of the Social Sciences Lecture Series held at PAA on June, $10^{\text {th }}$.

Nkwocha, S. (2010). "EFCC Advisory List". Leadership Weekend, October 30, P 19.

Nnochiri, I. (2013), "Jonathan's Govt. can't Fight Corruption -Tambuwal”, Daily Vanguard, on December, P. 12.

Nye, J. S., (1967) "Corruption and Political Development: A Case-Benefit Analysis", The American Political Science Review, Pp. 417-427

Opeselltan, T. (2010). "Daily Times: Adoke loses bid to Withdraw Fraud Charges against Anosike". Daily Independent, Friday, October, 28, P.2.

Shleifer, A. \& Vishnu, W.R. (1998). The Grabbing Hand: Government Pathologies and Their Cures. London: Oxford Publishers.

Tambuwal, A. W. (2013), "The Role Of The Legislature As The Vanguard For Anti Corruption Crusade In Nigeria," being text of the Speech at the 2013 International Anti-Corruption Day Organized By The Nigeria Bar Association (NBA) Anti-Corruption Committee - 9th December, Sheraton Hotel \& Towers, Abuja

Tukur, S. (2013), "President Jonathan Encourages Corruption In Nigeria, House Speaker Tambuwal Says," Premium Times, Dec 18, P. 18.

Tullock, G. (1996). "Corruption Theory and Practice". Contemporary Economic Policy, 14(3):6-13.

UNDDC and the World Bank (2007). Stolen Asset Recovery (SAR), Initiative: Challenges, Opportunities and Action Plan. Washington: World Bank.

United Nations, Office for Drug Control and Crime Prevention (2001). Anti-Corruption Tool Kit (CICP-15). (Available on-line at http://www.odccp.org/ corruption.html

Websters New Collegiate Dictionary, (1980), Springfield, Mass, USA: G. \& C. Merriam Company, 